\title{
PENGARUH LEADER MEMBER EXCHANGE, DAN KELELAHAN EMOSIONAL TERHADAP TURNOVER INTENTION PADA KARYAWAN PERTOKOAN DALUNG PERMAI
}

\author{
Agung Wachid Kurniawan ${ }^{1}$ \\ Made Surya Putra ${ }^{2}$ \\ ${ }^{1,2}$ Fakultas Ekonomi dan Bisnis, Universitas Udayana (Unud), Bali, Indonesia \\ email:bliwahid@gmail.com
}

\begin{abstract}
ABSTRAK
Tujuan penelitian ini adalah untuk mengetahui pengaruh leader member exchange, dan kelelahan emosional terhadap turnover intention pada karyawan. Penelitian ini dilakukan dipertokoan Dalung Permai. Jumlah sampel sebanyak 89 orang karyawan, dengan metode sampel jenuh atau sensus. Pengumpulan data dilakukan melalui wawancara dan kuesioner.Teknik analisis yang digunakan adalah regresi linearberganda.Berdasarkan hasil analisis ditemukan bahwa LMX secara parsial berpengaruh signifikan terhadap turnover intention, hal ini mengindikasikan bahwa semakin tinggi nilai LMX semakin rendah turnover intention. Kelelahan emosional secara parsial berpengaruh signifikan terhadap turnover intention, menunjukkan bahwa semakin tinggi kelelahan emosional karyawan semakin tinggi pula turnover intentionnya. Penelitian ini menunjukkan pengaruh negatif dan signifikan dari LMX terhadap turnover intention, dan pengaruh positif signifikan dari kelelahan emosional terhadap turnover intention.
\end{abstract}

Kata Kunci :Leader member exchange, kelelahan emosional, turnover intention.

\begin{abstract}
The purpose of this study was to determine the effect of leader member exchange, and emotional fatigue on turnover intention on employees. This research was conducted in the shop of Dalung Permai. The number of samples is 89 employees, using the method of saturated samples or census. Data collection is done through interviews and questionnaires. The analysis technique used is multiple linear regression. Based on the results of the analysis it was found that LMX partially had a significant effect on turnover intention, this indicates that the higher the LMX value the lower the turnover intention. Emotional fatigue partially has a significant effect on turnover intention, this shows the higher the employee's emotional fatigue the higher the turnover of his intention. This study shows a negative and significant effect of LMX on turnover intention, and a significant positive effect of emotional fatigue on turnover intention.
\end{abstract}

Keywords: Leader member exchange, emotional fatigue, turnover intention. 


\section{PENDAHULUAN}

Sumber daya manusia adalah aset perusahaan yang penting, dinamis dan dibutuhkan dalam tiap proses produksi barang maupun jasa. (Cascio, 1987;60) menegaskan bahwa manusia adalah sumber daya yang sangat penting dalam bidang industri dan organisasi, maka pengelolaannya yang mencakup penyediaan tenaga kerja yang bermutu, peningkatan kualitas dan pengendalian biaya ketenagakerjaan harus dikawal sebaik-baiknya. Berbagai penelitian menunjukkan bahwa pekerja yang memiliki sikap kerja positif akan menampakkan produktivitas yang lebih tinggi daripada pekerja sebaliknya. Pekerja yang memiliki sikap positif terhadap pekerjaan akan rendah tingkat absensi dan pengunduran dirinya (Gilmer, $1966 ; 62)$.

Terjadinya pengunduran diri karyawan atau turnover merupakan hal yang tidak dikehendaki oleh perusahaan. Turnover memang merupakan masalah klasik yang dihadapi para pengusaha sejak era revolusi industri. Kondisi lingkungan kerja yang buruk, upah yang terlalu rendah, jam kerja melewati batas, serta tiadanya jaminan sosial merupakan penyebab utama timbulnya turnover pada waktu itu (Hartati, 1992). Dewasa ini masalah turnover sangat diperhatikan oleh para pakar ekonomi dan sosial, karena jika ditinjau dari berbagai sisi, perusahaan akan mengalami kerugian (Handoyo, 1987). Turnover ini jika terjadi dalam manajemen menengah, maka kerugian yang ditanggung oleh perusahaan akan semakin membengkak (Hartati, 1992).

Turnover yang terjadi merugikan perusahaan baik dari segi biaya, sumber daya, maupun motivasi karyawan. Turnover yang terjadi berarti perusahaan kehilangan sejumlah tenaga kerja. Kehilangan ini harus diganti dengan karyawan baru. Perusahaan harus mengeluarkan biaya mulai dari perekrutan hingga mendapatkan tenaga kerja siap pakai. Keluarnya karyawan berarti ada posisi tertentu yang lowong dan harus segera diisi. Selama masa lowong maka tenaga kerja yang ada kadang tidak sesuai dengan tugas yang ada sehingga beberapa tugas menjadi terbengkalai. Karyawan yang tertinggal dalam perusahaan akan terpengaruh motivasi dan semangat kerjanya. Karyawan yang sebelumnya tidak berusaha mencari pekerjaan baru akan mulai mencari lowongan kerja, yang kemudian akan melakukan turnover. Hal ini jelas membawa kerugian maka perlu diusahakan pemecahannya. Salah satu upaya untuk mengurangi tingkat turnover yaitu dengan memperhatikan segala faktor yang menyebabkan keinginan karyawan untuk berpindah (turnover intention), menyesuaikan jam kerja, upah serta memberikan skema insentif yang baik untuk mempertahankan karyawan, namun keinginan karyawan untuk berpindah disikapi dengan sebuah keadaan dimana karyawan mulai mendapati kondisi kerjanya sudah tidak sesuai lagi dengan apa yang diharapkan seperti jenjang karir yang lambat, kenaikan gaji yang tidak sesuai harapan sehingga menimbulkan kelelahan emosional (Prawitasari, 2015;33). Penelitian oleh (Cascio, 1987;90) menunjukkan bahwa karyawan mengalami banyak permasalahan, di satu sisi karyawan dituntut untuk mampu bersaing di dalam lingkungan perusahaan dan mampu mewujudkan tujuan yang ingin dicapai oleh perusahaan, di sisi lain karyawan menghadapi banyak permasalahan yang menimbulkan stres. Karyawan yang frustasi dapat disebabkan oleh kelelahan emosional (Usman, 2012). Kelelahan emosional muncul karena 
stres berlebihan yang dapat mengantarkan individu pada keadaan yang lebih buruk dimana muncul apatisme, sinisme, dan frustasi (Widiastuti \& Kamsih., 2008). Sumber kelelahan emosional dapat muncul pada individu yang memiliki kecenderungan kepribadian perfeksionis atau menginginkan kesempurnaan pada setiap pekerjaannya (Caputo, 1991;70). kelelahan emosional, yaitu kelelahan pada seseorang yang berhubungan dengan perasaan yang ditandai dengan rasa tidak berdaya dan depresi (Pines \& Aronson, 1989). Kelelahan emosional selalu didahului dengan timbulnya rasa cemas setiap ingin memulai bekerja, kebiasaan buruk ini mengubah individu menjadi frustasi, atau marah pada diri sendiri (Babakus et al., 1999).

Permasalahan seperti ini kerap terjadi pada karyawan yang disebabkan oleh faktor lingkungan sosial ketika karyawan harus menghadapi konsumen dengan berbagai macam karakter, ada yang mudah menerima dan tak sedikit pula yang menolak. Masalah lain adalah perbedaan pendapat antara rekan kerja, kerjasama yang kurang baik antara karyawan, tekanan-tekanan kerja yang berkaitan dengan pencapaian target, terjadinya kecelakaan kerja dan kerja yang lebih berat. Permasalahan lain yang berkaitan dan berpengaruh dengan kenyamanan kerja adalah masalah kelelahan emosional yang dirasakan karyawan ketika berada di kantor walaupun menurutnya itu adalah tempat yang ideal dan nyaman. Ketidakpuasan dan perasaan iri juga muncul ketika rekan karyawan ada yang mampu memenuhi target bahkan over target.

Berdasarkan pemaparan tersebut dapat disimpulkan bahwa karyawan merupakan profesi yang menuntut seseorang agar selalu terlihat stabil secara emosionalmaupun secara fisiologis (Gilmer, 1966;87). Tuntutan seperti ini sangat mempengaruhi kelelahan emosional seseorang dan cenderung akan membuat orang tersebut merasa jenuh hingga akhirnya melakukan turnover maka dapat disimpulkan bahwa karyawan yang menuntut kekuatan emosional seringkali membuat mereka memutuskan untuk berhenti bekerja (turnover).

Karyawan sangat rentan terhadap stres mengingat sifat peran mereka. Kelelahan emosional karyawan sebagai penyebab intensi turnover dan pentingnya proses kepemimpinan LMX dalam mengurangi stres sangat penting untuk diteliti. Penelitian sebelumnya menunjukkan bahwa Leader Member Exchange LMX secara signifikan dapat mempengaruhi kelelahan emosional, dan Turnover Intention (Mahmoud et al., 2016). Tanggung jawab menjembatani jurang kerenggangan antara organisasi dan pelanggannya, menjadi penyebab terbesar bagi stres dan kelelahan yang signifikan bagi karyawan (Boles et al., 1997), dengan demikian, kemampuan karyawan untuk mengelola stres secara produktif merupakan perhatian utama organisasi. Salah satu sumber potensial untuk membantu karyawan yang mengalami gejala stres adalah empati dan dukungan orang lain di tempat kerja yang paling mencolok, karyawan mungkin mencari dukungan eksplisit dan implisit dari para manajer mereka.

Turnover karyawan diperkirakan meningkat dua kali lipat pada sebagian besar industri (Richardson, 1999). Hubungan antara karyawan dan manajer mempengaruhi bagaimana karyawan memandang pekerjaan mereka, misalnya, karyawan dengan hubungan LMX berkualitas tinggi bisa melaporkan peningkatan dan komitmen yang lebih tinggi terhadap organisasi mereka (DeConinck, 2011), 
bukti analisismenunjukkan bahwa LMX yang tinggi dapat meningkatkan komitmen organisasi dan memiliki dampak negatif pada intensi turnover (Gerstner \& Day, 1997), dan karyawan dengan hubungan LMX rendah mengalami tingkat konflik peran dan ambiguitas yang lebih tinggi.

Kelelahan emosional menyebabkan tingkat komitmen yang lebih rendah dan kemungkinan lebih tinggi untuk mencari pekerjaan alternatif (Cropanzano et al., 2003), beberapa tekanan diperlukan oleh organisasi tetapi membebani karyawan dengan tuntutan yang berlebihan dapat mengakibatkan perilaku berbahaya, meningkatnya tekanan kerja menyebabkan komitmen organisasi menurun dan kemungkinan lebih tinggi untuk mencari pekerjaan alternatif (Cropanzano et al., 2003). Demikian pula, kelelahan kerja dapat mengurangi kepuasan, kinerja, dan komitmen tenaga penjualan, sekaligus meningkatkan intensi turnover (Jones et al., 2007), secara keseluruhan, penelitian ini menunjukkan bahwa karyawan yang menderita frustrasi terkait dengan hubungan manajerial yang buruk cenderung meninggalkan organisasi daripada karyawan lainnya. Studi menunjukkan hubungan positif antara kelelahan dan turnover intention dimana karyawan harus mengatur emosi dirinya saat berhadapan dengan orang lain (Chau et al., 2009).

Ivancevich et al. (2007: 37) mengatakan bahwa leader member exchange (LMX) adalah pendekatan tentang adanya konsistensi perilaku atasan kepada bawahannya. Yukl (2004:14)menjelaskan bagaimana atasan dan bawahan mengembangkan hubungan saling mempengaruhi satu sama lain dan menegosiasikan peran bawahan dalam satu organisasi, LMX juga menekankan kualitas hubungan antara atasan dan bawahan.

Robins \& Judge (2008:25) membagi bawahan dalam 2 kategori, yaitu In group membersyang ada pada kategori ini adalah bawahan yang dapat diandalkan dalam berpartisipasi memberikan usaha yang lebih dari yang ditetapkan dalam job description. Atasan memperlakukan bawahan dalam kategori ini sebagai bawahan dengan penilaian kerja yang lebih tinggi, dan kepuasan kerja yang lebih baik karena hubungan ini memiliki kualitas hubungan yang tinggi.Out - group membersdalam kategori ini adalah bawahan yang melaksanakan tugas-tugasnya sesuai dengan job description formal mereka saja. Atasan akan memperlakukan bawahan dalam kategori ini sebagai bawahan yang memperoleh lebih sedikit waktu, penghargaan dan sedikit dukungan dari atasan karena hubungan ini memiliki kualitas hubungan yang rendah.

Nurjayadi (2004) mengatakan bahwa penurunan kerja individu merupakan dampak dari sikap dan perilaku negatif yang disebabkan oleh stres berlebihan yang menimbulkan kelelahan emosional. Kelelahan emosional merupakan respon individual unik terhadap stres yang dialami di luar kelaziman pada hubungan inter personal karena dorongan emosional yang kuat, timbulnya perasaan seakan tidak ada orang yang membantunya, depresi, perasaan terbelenggu dan putus asa (Zaglady, 2005). Kelelahan emosional berdampak buruk dan dapat mempengaruhi pekerjaan karyawan, seperti marah, dendam, masa bodoh, ketidakmampuan untuk berkonsentrasi sinis terhadap rekan kerja, bersikap menyalahkan, serta kaku dalam berpikir (Cherniss, 2001). Beberapa hal yang pada akhirnya mempengaruhi timbulnya kelelahan emosional pada seseorang. Menurut Houkes et al. (2003) 
terdapat empat indikator yang akan memudahkan dalam pengukuran kelelahan emosi, yaitu beban kerja, tekanan waktu, kurangnya dukungan sosial, stres karena peran.

Kelelahan emosional dalam diri seorang karyawan akan mempunyai konsekuensi atau dampak terhadap karyawan, utamanya pada turnover intention (Churiyah, 2011), hal ini berkaitan dengan teori peristiwa afektif, yang menyatakan sifat pekerjaan dan kebutuhan emosi karyawan berpengaruh terhadap kebiasaan dan sikap kerjanya (Cropanzano et al., 2003). Kombinasi dari konflik sehari-hari, peningkatan pengalaman pekerjaan dari karyawan dan kejadian lainnya akan menimbulkan efek emosi yang positif dan negatif yang mungkin akan mengarah pada sikap pekerjaan seperti kepuasan kerja dan komitmen organisasional (Ashkanasy et al., 2002)

Kelelahan emosional mengacu pada emosional yang berlebihan dan habisnya sumber daya emosional yang dialirkan seseorang kepada orang lain. Depersonalisasi mengacu pada suatu perasaan yang tidak menerima dan tanggapan bukan untuk memperdulikan pekerjaan atau melayani orang lain. Kemunduran kepribadian mengacu pada suatu perasaan kurangnya kemampuan atau wewenang dan prestasi sukses dalam pekerjaan orang-orang. Menurut Maslach et al. (2001) ada tiga aspek dalam kelelahan emosional :

Fisik. Secara individu ditandai dengan meningkatnya detak jantung dan tekanan darah, gangguan lambung, (gangguan gastrointestinal), mudah terluka, mudah lelah secara fisik, dan gangguan fisik lainnya.

Emosi. Kelelahan didalam emosi yaitu mudah lupa, sulit konsentrasi, mudah menangis, mengalami kebosanan, tidak percaya diri, putus asa, mudah cemas, gelisah, sulit beradaptasi, mengurung diri, mudah marah, kesepian.

Mental. Kelelahan yang berupa kecemasan, ketegangan, bingung, sensitif, memendam perasaan, komunikasi tidak efektif, timbulnya perasaan tidak bahagia, tidak berharga, gagal, merasa dirinya tidak berguna, kehilangan semangat hidup serta menurunya harga diri

Harnoto (2002:22) menyatakan turnover intention adalah kadar atau intensitas dari keinginan untuk keluar dari perusahaan. banyak alasan yang menyebabkan timbulnya turnover intention diantaranya adalah keinginan untuk mendapatkan pekerjaan yang lebih baik. turnover intention merupakan kecenderungan sikap atau tingkat di mana seorang memiliki kemungkinan untuk meninggalkan organisasi atau mundur secara sukarela dari pekerjaanya (Kent et al., 2001)

Keinginan berpindah mengacu pada hasil evaluasi individu mengenai kelanjutan hubungannya dengan organisasi dan belum menunjukkan tindakan pasti untuk meninggalkan organisasi (Lekatompessy, 2003). Kumar et al. (2011) mengklasifikasikan turnover intention ke dalam dua bagian yaitu turnover yang tidak dapat dicegah dan turnover yang tidak diinginkan. Turnover yang tidak dapat dicegah misalnya karena penyakit, masalah keluarga atau umur pensiun. sedangkanturnover yang tidak diinginkan misalnya karena ketidakmampuan karyawan dalam bekerja. atau merasa tidak nyaman di dalam organisasi. Turnoveryang tidak diinginkan pada karyawan dengan kompetensi tinggi dan berkualitas dapat terjadi karena masalah organisasi seperti kurangnya 
pengawasan, kurang dukungan dari atasan atau rekan kerja serta konflik peran yang dirasakan individu (Kumar et al., 2011). Turnover intention ditandai oleh perilaku karyawan, antara lain: absensi yang meningkat, malas bekerja, berani melanggar tata tertib dan menentang serta memprotes atasan (Harnoto, 2002:128).

Penelitian sebelumnya telah menunjukkan secara empiris peran penting LMX serta pengaruhnya terhadap turnover intention, Ketika pekerja merasakan hubungan yang seimbang antara mereka dengan pemimpin atau supervisor, pekerja akan lebih menikmati pekerjaan mereka dan akan mengurangi turnover intention (Kim et al., 2014). Namun dukungan pengawasan lebih bergantung pada hubungan emosional sedangkan leader-member exchange lebih bergantung pada kualitas hubungan interaktif (Shen et al., 2014). LMX berdampak negatif terhadap turnover intention (Gerstner \& Day, 1997). Penelitian Darrat et al., (2016) menunjukkan LMX berpengaruh negatif terhadap turnover intention. Penelitian. Ksama \& Wibawa (2016) menunjukkan LMX berpengaruh negatif signifikan terhadap turnover intention, berdasarkan berbagai hasil penelitian tersebut dapat dikemukakan hipotesis yang pertama sebagai berikut.

$\mathrm{H}_{1}$ : LMX berpengaruh negatif dan signifikan terhadap turnover intention.

Studi menunjukkan hubungan positif antara kelelahan emosional dengan turnover intention (Chau et al., 2009). Kelelahan emosional menurunkan tingkat komitmen dan memungkinkan untuk mencari alternatif pekerjaan (Cropanzano et al., 2003). Penelitian sebelumnya menunjukkan kelelahan emosional berpengaruh positif pada turnover intention (Mahmoud et al., 2016). Dengan begitu, dapat ditarik hipotesis kedua sebagai berikut.

$\mathrm{H}_{2}$ : Kelelahan emosional berpengaruh positif dan signifikan terhadap turnover intention.

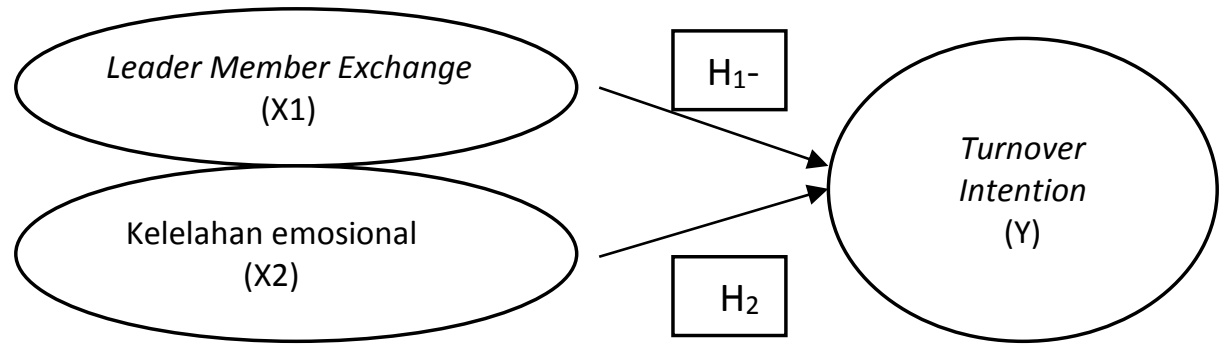

Gambar 1. Model Konseptual

\section{METODE PENELITIAN}

Penelitian yang dilakukan bersifat kuantitatif asosiatif yang bertujuan untuk mengetahui pengaruh antara dua variabel atau lebih (Sugiyono, 2017:5). Metode penelitian yang meneliti pada populasi tertentu dengan menggunakan pengumpulan data, instrumen penelitian berupan kuisioner, serta analisis data menggunakan uji statistik berganda.

Lokasi penelitian adalah pertokoan Perumahan Dalung Permai. Lokasi dipilih karena tingkat turnover intention karyawannya dianggap tinggi.Obyek penelitian adalah turnover intention karyawan, kelelahan emosional dan Leader Member Exchange $(L M X)$.Variabel bebas dalam penelitian ini adalah Leader 
Member Exchange (X1) dan kelelahan emosional (X2) Variabel terikat dalam penelitian ini adalah turnover intention karyawan (Y).

Leader Member Exchange (LMX)Dalam penelitian (Liden \& Maslyn, 1998) dijelaskan bahwa LMX adalah bersifat multi dimensional dan memiliki empat dimensi yaitu kontribusi, loyalitas, afeksi dan respek terhadap profesi, sebagai berikut:

Kontribusi berkaitan dengan kegiatan yang berorientasi pada tugas ditingkat tertentu antara setiap anggota untuk mencapai tujuan bersama. Hal penting dalam mengevaluasi kegiatan yang berorientasikan pada tugas adalah suatu tingkat dimana bawahan bertanggung jawab dan menyelesaikan tugas melebihi uraian kerja, demikian halnya pada atasan yang menyediakan sumber daya dan kesempatan untuk melakukan hal tersebut.Loyalitas adalah ungkapan untuk mendukung penuh tujuan dan sifat individu lainnya dalam hubungan timbal balik atasan dan bawahan. Loyalitas menyangkut pada kesetiaan penuh terhadap seseorang secara konsisten dari suatu situasi ke siatuasi lainnya.

Afeksi adalah perasaan peduli antara atasan dan bawahannya terutama pada daya tarik antar individu dan bukan hanya pada pekerjaan atau nilai profesionalnya saja. Bentuk kepedulian yang demikian dapat ditunjukkan dalam suatu keinginan untuk melakukan hubungan yang menguntungkan dan bermanfaat, seperti antar sahabat.Respek terhadap profesi adalah persepsi mengenai sejauh mana pada setiap hubungan timbal balik telah memiliki dan membangun reputasi di dalam dan di luar organisasi, melebihi apa yang telah ditetapkan di dalam pekerjaan.

Maslach et al. (2001) menyatakan bahwa kelelahan emosional termasuk dalam dimensi burnout bersama dua dimensi lainnya. Fisik. secara individu ditandai dengan meningkatnya detak jantung dan tekanan darah, gangguan lambung, mudah terluka, mudah lelah secara fisik, kematian, gangguan pernapasan, berkeringat, ketegangan otot, sulit tidur, mual-mual, sakit kepala, mudah terkena flu, Emosi. Kelelahan didalam emosi yaitu mudah lupa, sulit konsentrasi, mudah menangis, mengalami kebosanan, tidak percaya diri, putus asa, mudah cemas, gelisah, sulit beradaptasi, mengurung diri, mudah marah, kesepian. Mental. merupakan kelelahan yang berupa kecemasan, ketegangan, bingung, sensitif, memendam perasaan, komunikasi tidak efektif, tidak bahagia, tidak berharga, gagal, tidak berguna, kehilangan semangat hidup serta menurunnya harga diri dan rasa percaya diri. Lum (1998) mengartikan keinginan berpindah sebagai keinginan individu untuk keluar dari organisasi, keinginan berpindah dijelaskan sebagai perilaku yang memicu turnover.

Dimensi keinginan berpindah menurut Lum (1998) yaitu keinginan untuk mencari pekerjaan baru, pada bidang yang sama dengan perusahaan yang berbeda, yang disebabkan oleh perasaan karyawan yang tidak mengalami kemajuan pada pekerjaannya saat ini ataupun ketika individu merasa mudah mencari profesi tersebut. Maka dimensi ini diukur melalui persepsi keinginan responden untuk mencari pekerjaan baru baik dalam bidang yang sama ataupun tidak yang mendorong karyawan untuk keluar dari perusahaan. Keinginan meninggalkan perusahaan, diukur dari persepsi keinginan responden untuk meninggalkan 
perusahaan didasarkan pada beberapa pemikiran, evaluasi, serta niat pribadi dari karyawan yang bersangkutan.

Jenis data penelitian ini adalah kuantitatif dan kualitatif sebagai berikut.Data kuantitatif berupa jumlah responden serta hasil tabulasi dari kuisioner.Data kualitatif meliputi lokasi serta gambaran umum pada lokasi penelitian. Sumber data penelitian ini terbagi menjadi primer dan sekunder.Data primer, yang dikumpulkan dengan kuisioner sesuai instrumen yang diberikan kepada responden.Data sekunder, sebagai pendukung data primer yang telah dicatat seperti jumlah karyawan, laporan turnover perusahaan dan lain sebagainya.

Populasi dalam penelitian ini adalah semua karyawan toko retail di perumahan Dalung Permai yang berjumlah 89orang. Sampel yang diambil dari keseluruhan jumlah populasi. Teknik penentuan sampel yang digunakan adalah sampel jenuh atau sensus

Metode pengumpulan data menggunakan instrumen penelitian berupa kuisioner yang diisi langsung oleh para responden. Kuisioner adalah metode yang efisien karena variabel yang diketahui sudah pasti adanya dan jawaban yang diberikan responden dapat dimengerti sesuai harapan peneliti, kuisioner cocok digunakan ketika jumlah responden besar (Sugiyono, 2017:32).

Leader-member exchange (LMX) diukur dengan skala 11-item (Liden \& Maslyn, 1998). Kelelahan emosional diukur dengan adaptasi 5 item (Maslach et al., 2001) dan turnover intention diukur dengan 4 item Lum (1998). Responden diminta untuk menunjukkan frekuensi kecocokan mereka dalam perilaku yang diukur dengan menggunakan skala Likert 5-titik ( 1 = "sangat tidak setuju" dan $5=$ "sangat setuju").

Uji Validitas, untuk mengukur keandalan dan ketepatan instrumen yang digunakan, instrumen valid adalah yang benar-benar tepat untuk mengukur apa yang hendak diukur (Sugiyono, 2017:10). Instrumen dikatakan valid jika nilai korelasi Pearson Product Moment r-hitung>r-tabel (Siregar, 2014:21). Uji Reliabilitas, untuk menunjukkan bahwa kuisioner merupakan indikator dari setiap variabel. Pengujian menggunakan hasil koefisien cronbach alpha yangmelebihi 0.6 menunjukkan keandalan suatu instrumen (Sugiyono, 2017:33).

Analisis regresi linear berganda yang digunakan untuk mengetahui ketergantungan, besar dan arah variabel terikat (turnover intention) dengan variabel bebas (kelelahan emosional, leader member exchange) serta mengukur derajat keeratan hubungan antar variabel. Peneliti dibantu dengan program komputer Statistical Package Of Social Science (SPSS) 22.0 persamaan regresi linear berganda yang digunakan adalah sebagai berikut:

$\mathrm{Y}=\alpha+\beta_{1} x_{1}+\beta_{2} x_{2}$

Keterangan:

$\mathrm{Y}$ : Keinginan Berpindah Karyawan

$\alpha$ : Bilangan Konstan

$\beta_{1}$ : Koefisien regresi variabel $\beta_{1}$

$x_{1}$ : Leader Member Exchange

$\beta_{2}$ : Koefisien regresi variabel $\beta_{2}$

$x_{2}:$ Turnover Intention 
Uji asumsi klasik mencakup: uji multikolinieritas, uji autokorelasi, uji heteroskedastisitas, dan uji normalitas dilakukan sebelum uji regresi linier berganda (Sugiyono, 2017:43). Uji Normalitas, menurut (Sugiyono, 2017: 43-44) bertujuan untuk mengetahui apakah variabel dalam model regresi berdistribusi normal ataukah tidak. Model regresi yang baik adalah memiliki distribusi data normal atau mendekati normal. Jika nilai asymp. sigmodel Kolmogorof-Smirnov melebihi alpa 5\%, maka data variabel berdistribusi normal. Sehingga, model regresi memenuhi asumsi normalitas.Uji Heteroskedastisitas, menurut (Sugiyono, 2017:44) bertujuan untuk mengetahui apakah dalam model regresi terjadi ketidaksamaan variance dari residual satu pengamatan ke pengamatan yang lain. Model yang baik seharusnya tidak terjadi heteroskedastisitas. Untuk mengetahui ada tidaknya heteroskedastisitas dilakukan dengan pendekatan scatterplot. Jika grafik plot menunjukkan tidak beraturan dinyatakan tidak terjadi heteroskedastisitas. Uji multikolinieritas, menurut (Sugiyono, 2017:45) bertujuan untuk mengetahui apakah dalam model regresi ada korelasi antar variabel bebas. Model yang baik tidak terjadi korelasi di antara variabel bebas. Untuk mengetahui ada tidaknya multikolinieritas dilakukan dengan pendekatan VIF (Variance Inflation Factor). Jika nilainya $<10$, berarti tidak terjadi multikolinieritas.

\section{HASIL DAN PEMBAHASAN}

Perumahan Dalung Permai adalah sebuah perumahan yang terletak di desa Dalung, Kecamatan Kuta Utara, Kabupaten Badung, Bali. Awalnya wilayah yang menjadi Perumahan Dalung Permai sekarang ini merupakan wilayah semaksemak dan tegalan, yang terdiri dari tanah persawahan yang subur. Perumahan Dalung Permai merupakan perumahan yang memiliki kepadatan penduduk yang cukup tinggi mencapai 7.000 kepala keluarga dalam satu perumahan, karena perumahan tersebut memiliki akses jalan menuju ke tempat kerja baik di pemerintahan, swasta maupun ke sekolah-sekolah serta pusat-pusat perbelanjaan dan hiburan. Tingkat kepadatan penduduk yang tinggi, mendorong penyedia kebutuhan harian pada perumahan tersebut jadi sangatlah banyak, dalam satu komplek pertokoan terdapat 50 jenis usaha yang beragam mulai makanan siap saji seperti "nasi jinggo", pertokoan ritel, restoran, hingga rumah sakit. Tenaga kerja di pertokoan ini sangat menarik untuk diteliti karena tingkat kepadatan penduduk di daerah tersebut akan mempengaruhi jam kerja karyawan, dinamisnya pelanggan memengaruhi tingkat kelelahan emosional dan keinginan berpindah karyawan dipertokoan, serta bagaimana leader member exchange mempengaruhi variabel tersebut.

Data responden yang diperoleh dari hasil kuesioner yang telah disebar berdasarkan jenis kelamin dipaparkan dalam Tabel 1.

Tabel 1.

Distribusi Responden Berdasarkan Jenis Kelamin.

\begin{tabular}{ccc}
\hline Jenis Kelamin & Jumlah Responden (orang) & Persentase \\
\hline Perempuan & 59 & 66,3 \\
Laki-laki & 30 & 33,7 \\
Jumlah & 89 & 100 \\
\hline Sumber $:$ Data diolah 2018 & &
\end{tabular}

Sumber : Data diolah, 2018 
Tabel 1. artinya karyawan yang bekerja di Dalung permai dominan perempuan sebesar 59 orang $(66,3 \%)$ sisanya adalah laki-laki yang disebabkan oleh tingginya kebutuhan tenaga kerja perempuan yang lebih tinggi.Data responden yang diperoleh dari hasil kuesioner yang telah disebar berdasarkan usia dipaparkan dalam Tabel 2.

Tabel 2.

Distribusi Responden Berdasarkan Usia.

\begin{tabular}{ccc}
\hline Usia (Tahun) & Responden (orang) & Persentase \\
\hline $20-25$ & 49 & 55,06 \\
$26-30$ & 31 & 34,83 \\
$31-35$ & 4 & 4,49 \\
$>35$ & 5 & 5,62 \\
Jumlah & 89 & 100 \\
\hline
\end{tabular}

Sumber : Data diolah, 2018

Tabel 2. menunjukkan bahwa responden didominasi oleh pemuda/i berusia $20-25$ tahun sebanyak 49 orang $(55,06 \%)$ yang merupakan usia produktif sisanya dengan usia bervariasi hingga tertinggi adalah 40 tahun.

Data responden yang diperoleh dari hasil kuesioner yang telah disebar berdasarkan masa kerja dipaparkan dalam Tabel 3menunjukkan bahwa responden sesuai dengan tingkat usianya memiliki masa kerja mayoritas 1-5 tahun sebanyak 69 orang $(77,59 \%)$. Sisanya memiliki masa kerja bervariasi hingga yang terlama adalah 12 tahun.

Tabel 3.

Distribusi Responden Berdasarkan masa kerja.

\begin{tabular}{ccc}
\hline $\begin{array}{c}\text { Masa Kerja } \\
\text { (Tahun) }\end{array}$ & $\begin{array}{c}\text { Jumlah Responden } \\
\text { (orang) }\end{array}$ & Persentase \\
\hline $1-5$ & 69 & 77,59 \\
$6-10$ & 16 & 17,98 \\
$>10$ & 4 & 4,49 \\
Jumlah & 89 & 100 \\
\hline
\end{tabular}

Sumber : Data diolah, 2018

Sebuah instrumen dikatakan valid apabila dapat digunakan untuk mengukur apa yang seharusnya diukur. Pengujian validitas tiap butir pertanyaan atau pernyataan dalam instrumen penelitian ini mengkorelasikan skor tiap item dengan skor total item. Nilai korelasi antar skor item dengan total item dibandingkan dengan $r$ kritis. Jika korelasi item terhadap skor total lebih besar dari r kritis $(0,30)$ maka instrumen dikatakan valid. Hasil uji validitas instrumen penelitian disajikan pada Tabel 4.

Tabel 4.

Hasil Uji Validitas

\begin{tabular}{|c|c|c|c|c|}
\hline No & Variabel & $\begin{array}{c}\text { Item } \\
\text { Pernyataan }\end{array}$ & $\begin{array}{c}\text { Korelasi Item } \\
\text { Total }\end{array}$ & $\begin{array}{c}\text { Keteranga } \\
\text { n }\end{array}$ \\
\hline
\end{tabular}




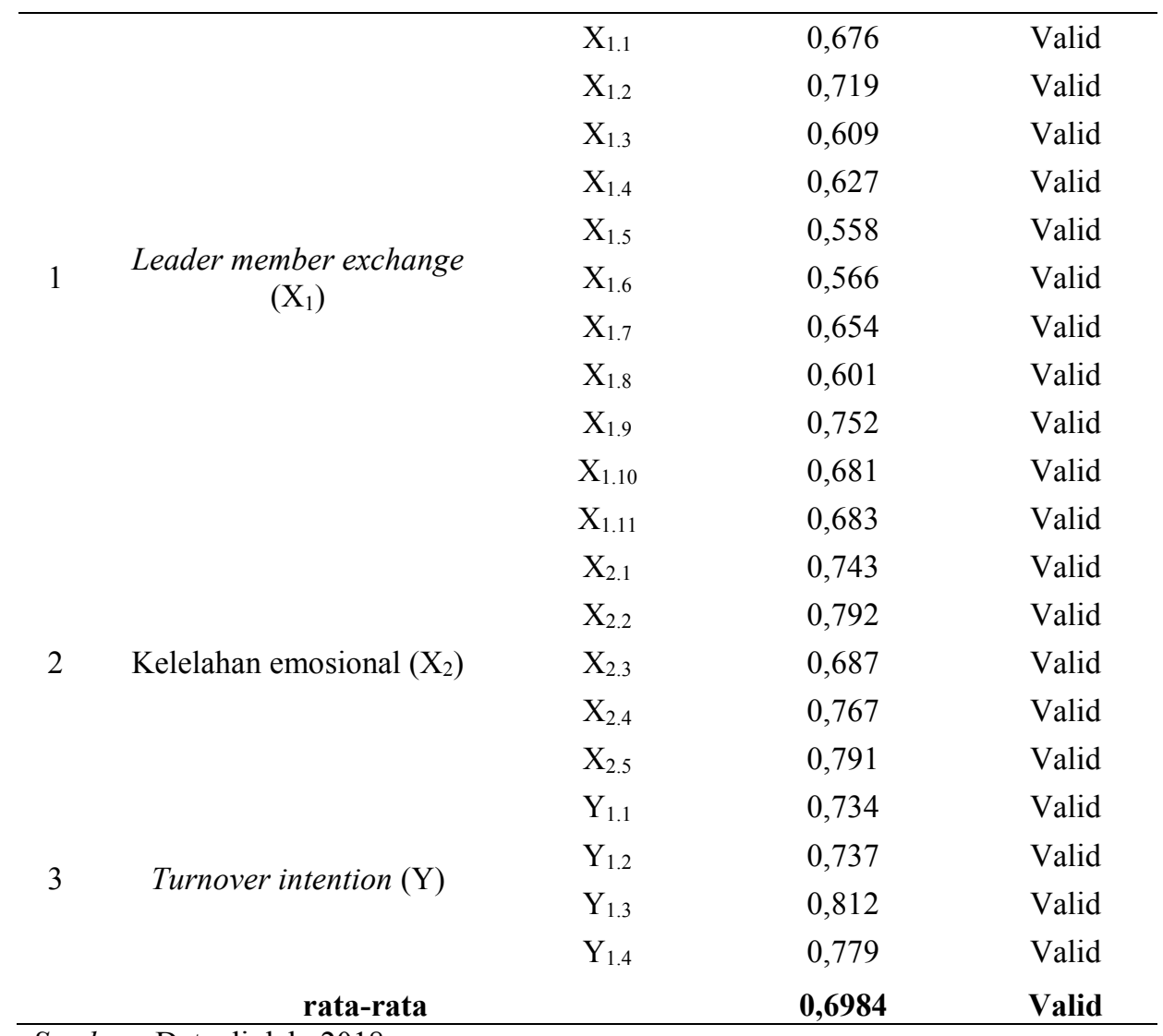

Sumber : Data diolah, 2018

Berdasarkan uji validitas pada Tabel 4. menunjukkan seluruh pernyataan variabel leader member exchange, kelelahan emosional, dan turnover intention memiliki skor rata-rata total koefisien product moment correlation pearson seluruh item 0,6984 pernyataan ini lebih besar dari 0,30, sehingga seluruh indikator telah memenuhi syarat validitas data dan dinyatakan valid.

Melalui uji reliabilitas instrumen, suatu alat pengukur dapat dipakai dua kali mengukur gejala yang sama dengan hasil pengukuran relatif konsisten. Pengujian reliabilitas tiap butir pertanyaan atau pernyataan dalam instrumen penelitian ini menggunakan metode koefisien Cronbach's Alpha. Instrumen dikatakan reliabel untuk mengukur variabel bila berada di atas angka 0,60. Hasil pengujian reliabilitas instrumen dapat dilihat pada Tabel 5.

Tabel 5.

Hasil Uji Reliabilitas

\begin{tabular}{llll}
\hline No & \multicolumn{1}{c}{ Variabel } & Cronbach's Alpha & Keterangan \\
\hline 1 & Leader member exchange $\left(\mathrm{X}_{1}\right)$ & 0,859 & Reliabel \\
2 & Kelelahan emosional $\left(\mathrm{X}_{2}\right)$ & 0,81 & Reliabel \\
3 & Turnover intention $(\mathrm{Y})$ & 0,764 & Reliabel \\
\hline \multicolumn{2}{l}{ Sumber $:$ Data diolah, 2018} & &
\end{tabular}

Berdasarkan Tabel 5. ditunjukkan bahwa ketiga instrumen penelitian leader member exchange, kelelahan emosional dan turnover intention memiliki koefisien 
Cronbach's Alpha lebih besar dari 0,60 sehingga seluruh pernyataan tersebut memenuhi syarat dan dinyatakan reliabel.

Kuesioner yang digunakan terdiri atas pernyataan yang dibuat berdasarkan masing-masing variabel, yaitu: variabel leader member exchange, kelelahan emosional, dan turnover intention. Pendiskripsian penilaian responden menggunakan konversi, jawaban responden digolongkan ke dalam beberapa skala pengukuran dengan kriteria tertentu. Ketentuan dalam menentukan interval kelas sebagai berikut:

Skor untuk masing-masing jawaban variabel penelitian adalah minimal 1 dan maksimal 5, maka interval setelah dihitung dengan menggunakan rumus diatas sebagai berikut.

$$
\begin{aligned}
& \text { Interval }=\frac{\text { Nilai tertinggi }- \text { Nilai Terendah }}{\text { Jumlah Kelas }} \\
& \text { Interval }=\frac{5-1}{5}=0,8
\end{aligned}
$$

Penilaian variabel-variabel penelitian secara menyeluruh akan dilihat dari rata-rata skor dengan kriteria sebagai berikut.

$1,00-1,79=$ sangat rendah

$1,80-2,59=$ rendah

$2,60-3,39=$ cukup

$3,40-4,19=$ tinggi

$4,20-5,00=$ sangat tinggi

Variabel leader member exchange merupakan variabel bebas yang diukur dengan menggunakan 11 pernyataan yang berhubungan dengan leader member exchange. Berdasarkan hasil penelitian dapat diketahui jawaban responden secara rinci pada Tabel 6.

Data pada Tabel 6. menunjukkan 11 pernyataan leader member exchange memperoleh nilai tinggi, artinya responden sudah merasakan leader member exchange yang terjadi. Nilai rata-rata tertinggi ada pada pernyataan "Saya menghormati kompetensi atasan saya dalam pekerjaannya" dengan nilai rata-rata 4,15. Artinya responden menghormati kemampuan dan pengetahuan yang dimiliki atasannya. Nilai rata-rata terendah jawaban responden ditunjukkan pada pernyataan "Atasan saya membela saya dari atasan lainnya meski tidak menguasai duduk perkaranya" dengan nilai rata-rata sebesar 3,10.

\begin{tabular}{|c|c|c|c|c|c|c|c|c|}
\hline \multirow{2}{*}{ No. } & \multirow{2}{*}{ Pernyataan } & \multicolumn{5}{|c|}{ Distribusi Jawaban } & \multirow{2}{*}{$\begin{array}{l}\text { Rata- } \\
\text { rata }\end{array}$} & \multirow{2}{*}{ Kriteria } \\
\hline & & STS & TS & $\mathbf{N}$ & $\mathbf{S}$ & SS & & \\
\hline 1 & $\begin{array}{l}\text { Saya bersedia bekerja ekstra melebihi } \\
\text { kewajiban demi memenuhi tujuan } \\
\text { kerja yang diinginkan atasan saya. }\end{array}$ & 1 & 16 & 25 & 37 & 10 & 3,44 & Tinggi \\
\hline 2 & $\begin{array}{l}\text { Saya tidak berkeberatan bekerja } \\
\text { sangat keras untuk atasan saya. }\end{array}$ & 2 & 19 & 32 & 22 & 14 & 3,3 & Cukup \\
\hline 3 & Saya bersedia bekerja ekstra melebihi & 0 & 22 & 21 & 34 & 12 & 3,4 & Tinggi \\
\hline
\end{tabular}

Tabel 6.

Deskripsi Jawaban Mengenai Variabel Leader Member Exchange 


\begin{tabular}{|c|c|c|c|c|c|c|c|c|}
\hline 4 & $\begin{array}{l}\text { Atasan saya membela saya jika ada } \\
\text { yang "menyerang" saya. }\end{array}$ & 0 & 6 & 18 & 44 & 21 & 3,9 & Tinggi \\
\hline 5 & $\begin{array}{l}\text { Atasan saya membela saya dari } \\
\text { atasan lainnya meski tidak menguasai } \\
\text { duduk perkaranya. }\end{array}$ & 2 & 24 & 32 & 25 & 6 & 3,1 & Cukup \\
\hline 6 & $\begin{array}{l}\text { Atasan saya membela saya dari pihak } \\
\text { lain jika saya berbuat kesalahan dan } \\
\text { mengakuinya. }\end{array}$ & 1 & 9 & 29 & 38 & 12 & 3,57 & Tinggi \\
\hline 7 & $\begin{array}{l}\text { Atasan saya punya banyak humor } \\
\text { yang menghibur. }\end{array}$ & 0 & 13 & 21 & 35 & 20 & 3,7 & Tinggi \\
\hline 8 & $\begin{array}{l}\text { Atasan saya akan disukai orang lain } \\
\text { sebagai teman. }\end{array}$ & 1 & 6 & 22 & 44 & 16 & 3,76 & Tinggi \\
\hline 9 & $\begin{array}{l}\text { Saya sangat respek } \\
\text { pengetahuan atasan saya } \\
\text { pekerjaannya. }\end{array}$ & 0 & 6 & 10 & 49 & 24 & 4,02 & Tinggi \\
\hline 10 & $\begin{array}{l}\text { Saya kagum dengan keahlian } \\
\text { profesional atasan saya }\end{array}$ & 1 & 5 & 15 & 43 & 25 & 3,97 & Tinggi \\
\hline 11 & $\begin{array}{l}\text { Saya menghormati kompetensi atasan } \\
\text { saya dalam pekerjaannya. }\end{array}$ & 1 & 3 & 7 & 49 & 29 & 4,15 & Tinggi \\
\hline & Total & & & & & & 3,66 & Tinggi \\
\hline
\end{tabular}

Sumber : Data diolah, 2018

Variabel kelelahan emosional diukur menggunakan 5 pernyataan tentang kelelahan emosional responden. Berdasarkan hasil penelitian diketahui jawaban responden secara rinci pada Tabel 7.

Tabel 7.

Deskripsi Jawaban Responden Mengenai Kelelahan Emosional

\begin{tabular}{|c|c|c|c|c|c|c|c|c|}
\hline \multirow{2}{*}{ No. } & \multirow{2}{*}{ Pernyataan } & \multicolumn{5}{|c|}{ Distribusi Jawaban } & \multirow{2}{*}{$\begin{array}{l}\text { Rata- } \\
\text { rata }\end{array}$} & \multirow{2}{*}{ Kriteria } \\
\hline & & STS & TS & $\mathbf{N}$ & $\mathbf{S}$ & SS & & \\
\hline 1 & $\begin{array}{l}\text { Saya sering melupakan } \\
\text { kewajiban utama dalam bekerja. }\end{array}$ & 3 & 12 & 15 & 36 & 23 & 2,28 & Rendah \\
\hline 2 & $\begin{array}{l}\text { Saya merasakan kesulitan } \\
\text { berkonsentrasi dalam bekerja }\end{array}$ & 2 & 13 & 28 & 35 & 11 & 2,55 & Rendah \\
\hline 3 & $\begin{array}{l}\text { Saya merasakan kebosanan } \\
\text { dalam bekerja }\end{array}$ & 3 & 19 & 38 & 21 & 8 & 2,87 & Cukup \\
\hline 4 & $\begin{array}{l}\text { Saya mudah marah dengan } \\
\text { orang-orang di sekitar saya. }\end{array}$ & 1 & 9 & 26 & 41 & 12 & 2,39 & Rendah \\
\hline 5 & $\begin{array}{l}\text { Saya merasakan kesedihan } \\
\text { tanpa alasan pada saat bekerja. }\end{array}$ & 2 & 14 & 20 & 38 & 15 & 2,44 & Rendah \\
\hline & Total & & & & & & 2,51 & Rendah \\
\hline
\end{tabular}

Sumber : Data diolah, 2018

Data pada Tabel 7.menunjukkan nilai rata-rata kelelahan emosional 2.51 termasuk rendah, artinya reponden memiliki kelelahan emosional yang rendah. Nilai rata-rata tertinggi ada pada pernyataan "Saya merasakan kebosanan dalam bekerja" dengan nilai 2,87 artinya responden merasa bosan dalam bekerja. Nilai rata-rata terendah ada pada pernyataan "Saya sering melupakan kewajiban utama saya dalam bekerja." artinya meski bosan karyawan tidak melupakan tanggung jawab dalam melakukan pekerjaan.

Variabel turnover intention merupakan variabel terikat yang diukur dengan menggunakan 4 pernyataan tentang turnover intention. Berdasarkan hasil penelitian diketahui jawaban responden secara rinci pada Tabel 8 . 
Tabel 8.

Deskripsi Jawaban Responden Mengenai Variabel Turnover Intention

\begin{tabular}{|c|c|c|c|c|c|c|c|c|}
\hline \multirow{2}{*}{ No. } & \multirow{2}{*}{ Pernyataan } & \multicolumn{5}{|c|}{ Distribusi Jawaban (\%) } & \multirow{2}{*}{$\begin{array}{l}\text { Rata- } \\
\text { rata }\end{array}$} & \multirow{2}{*}{ Kriteria } \\
\hline & & STS & TS & $\mathbf{N}$ & $\mathbf{S}$ & SS & & \\
\hline 1 & $\begin{array}{l}\text { Saya ingin pindah ke perusahaan } \\
\text { lain tetapi masih dalam bidang } \\
\text { yang sama. }\end{array}$ & 5 & 14 & 23 & 36 & 11 & 2,62 & Cukup \\
\hline 2 & $\begin{array}{l}\text { Saya ingin mencoba pengalaman } \\
\text { baru di bidang yang berbeda. }\end{array}$ & 12 & 38 & 23 & 12 & 4 & 3,47 & Tinggi \\
\hline 3 & 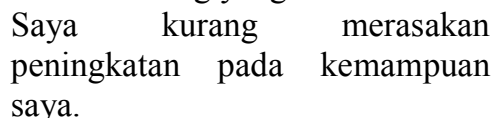 & 7 & 22 & 26 & 30 & 4 & 2,98 & Cukup \\
\hline 4 & $\begin{array}{l}\text { Saya merasa sudah cukup lama } \\
\text { bekerja disini. }\end{array}$ & 7 & 20 & 36 & 20 & 6 & 3,02 & Cukup \\
\hline & Total & & & & & & 3,02 & Cukup \\
\hline
\end{tabular}

Sumber : Data diolah, 2018

Data Tabel 8. menunjukkan 4 pernyataan turnover intention memperoleh nilai rata-rata 3,02 termasuk cukup. Artinya banyak responden merasakan turnover intention. Nilai rata-rata tertinggi ada pada "Saya ingin mencoba pengalaman baru di bidang yang berbeda" dengan nilai rata-rata 3,47. Artinya mencoba hal baru sangat mempengaruhi responden dalam melakukan turnover intention. Selanjutnya, nilai rata-rata terendah jawaban responden ditunjukkan pada pernyataan "Saya ingin pindah ke perusahaan lain tetapi masih dalam bidang yang sama." dengan nilai rata-rata sebesar 2,62.

Model analisis regresi linear berganda digunakan untuk mendapat koefisien regresi yang menentukan hipotesis yang dibuat akan diterima atau ditolak. Hasil analisis ini mengacu pada hasil pengaruh leader member exchange, dan kelelahan emosional terhadap turnover intention. Adapun hasil analisis regresi dengan program Statistical Package of Social Science (SPSS) versi 22.0 for Windows dapat dilihat pada Tabel 9 berikut. Berdasarkan Tabel 9 maka persamaan regresi linear berganda adalah:.

$$
\begin{aligned}
& \mathrm{Y}=14,623-0,198 \mathrm{X}_{1}+0,436 \mathrm{X}_{2} \\
& \mathrm{Keterangan}: \\
& \mathrm{Y}=\text { Turnover intention } \\
& \mathrm{X}_{1}=\text { Leader member exchange } \\
& \mathrm{X}_{2}=\text { kelelahan emosional }
\end{aligned}
$$

Tabel 9.

Rangkuman Hasil Analisis Regresi Linear Berganda

\begin{tabular}{llllll}
\hline \multicolumn{2}{c}{ Variabel } & \multicolumn{2}{c}{ Koefisien Regresi } & \multirow{2}{*}{ T } & \multirow{2}{*}{ Sig } \\
\cline { 2 - 4 } & \multicolumn{1}{c}{ B } & Std. Error & & \\
\hline Leader member exchange & $-0,198$ & 0,04 & $-4,919$ & 0 \\
Kelelahan emosional & 0,436 & 0,07 & 6,217 & 0 \\
(Constant) & $: 14,623$ & & & & \\
F Statistik & $: 31,546$ & & & &
\end{tabular}




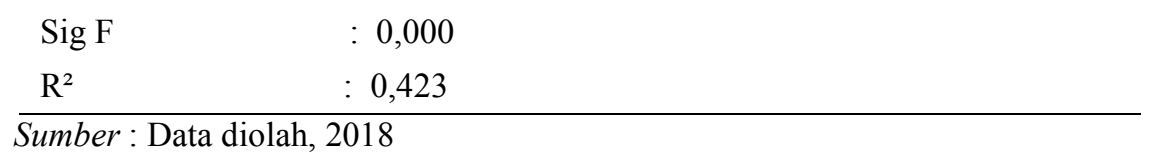

Persamaan regresi linear berganda menunjukkan arah variabel bebas. Persamaan tersebut dapat diuraikan sebagai berikut $: \mathrm{X}_{1}=0,198$, menunjukkan leader member exchange berpengaruh negatif terhadap turnover intention, apabila leader member exchange membaik maka turnover intentionakan mengalami penurunan. $\mathrm{X}_{2}=0,436$, artinya kelelahan emosional berpengaruh positif terhadap turnover intention, jika kelelahan emosional mengalami peningkatan maka turnover intentionakan mengalami peningkatan. $\mathrm{R}^{2}=0,423$ artinya 42,3 persen turnover intention karyawan dipengaruhi oleh leader member exchange dan kelelahan emosional, sisanya sebesar 57,7 persen dipengaruhi oleh variabel lainnya di luar model penelitian.Uji Anova ( $F$ test) 31,546 , sigF $0,000<\alpha=0,05$, artinya LMXdan kelelahan emosional bisa memprediksi turnover intention, maka model ini layak uji t.

Model regresi linear berganda secara teori menghasilkan nilai parameter penduga yang tepat bila memenuhi persyaratan asumsi klasik regresi, yaitu: uji normalitas, multikolinearitas, dan heteroskedastisitas.Model diuji secara kuantitatif dengan Kolmogrov-Smirnov. Data dikatakan berdistribusi normal saat Asimp.sig >level of significant $(\alpha=0,05)$.

Tabel 10.

Hasil Uji Normalitas

\begin{tabular}{llr}
\hline & & $\begin{array}{c}\text { Unstandardized } \\
\text { Residual }\end{array}$ \\
\hline $\mathrm{N}$ & Mean & 89 \\
Normal Parameters & a,b & .0000000 \\
& Std. Deviation & 242.519 .310 \\
& Absolute & .059 \\
Most Extreme Differences & Positive & .059 \\
& Negative & -.050 \\
Test Statistic & & .059 \\
Asymp. Sig. & & $.200^{\text {c,d }}$ \\
\hline : Data diolah, 2018 & &
\end{tabular}

Sumber : Data diolah, 2018

Pada Tabel 10. nilai Asymp. Sig. 0,200 lebih besar dari $\alpha=0,05$. Jadi, data tersebut memenuhi syarat normalitas dan berdistribusi normal.Model regresi yang baik seharusnya tidak terjadi korelasi diantara variabel bebasnya. Berdasarkan aturan variance inflation factor (VIF) dan tolerance, apabila VIF melebihi angka 10 atau tolerance kurang dari 0,10 maka terjadi gejala multikolinearitas.

Table 11.

\begin{tabular}{lll}
\multicolumn{3}{l}{ Hasil Uji Multikolinearitas (Tolerance dan VIF) } \\
\hline \multirow{2}{*}{ Variabel } & \multicolumn{2}{l}{$\begin{array}{l}\text { Collinearity } \\
\text { Tolatistics }\end{array}$} \\
& Tolerance & VIF \\
\hline Leader member exchange & 1 & 1 \\
Kelelahan emosional & 1 & 1 \\
\hline
\end{tabular}


Sumber : Data diolah, 2018

Hasil pengujian tolerance menunjukan seluruh variabel bebas memiliki nilai tolerance lebih besar dari 0,10 (10\%). Hasil perhitungan VIF juga menunjukan bahwa seluruh variabel bebas memiliki nilai VIF kurang dari 10. Oleh karena itu, disimpulkan bahwa tidak terjadi multikolinearitas antar variabel independen dalam model regresi tersebut.

Uji heteroskedasitas menguji apakah dalam model regresi terjadi ketidaksamaan varian dari residual satu pengamatan ke pengamatan yang lain..Metode glejser dilakukan dengan meregresikan variabel bebas terhadap absolut residual, jika tingkat signifikansi masing-masing variabel bebas lebih besar dari 0,05 maka disimpulkan bahwa tidak terdapat heteroskedastisitas. Hasil uji heteroskedastisitas ditunjukkan dalam Tabel 12 berikut ini:

Tabel 12.

Hasil Uji Heteroskedastisitas (Metode Glejser)

\begin{tabular}{lll}
\hline Variabel & T & Signifikansi \\
\hline Leader member exchange & $-0,318$ & 0,751 \\
Kelelahan emosional & 1,513 & 0,134 \\
Sumber $:$ Data diolah, 2018 & &
\end{tabular}

Hasil pengujian menunjukkan bahwa signifikansinya lebih dari $\alpha=0,05$ terhadap absolut residual secara parsial, maka disimpulkan bahwa dalam model regresi tersebut tidak terdapat heteroskedastisitas. Uji parsial (uji t) menguji pengaruh masing-masing variabel bebas (leader member exchange dan kelelahan emosional) terhadap variabel terikat (turnover intention). Tabel 13 menunjukkan hasil perhitungan uji t dengan menggunakan SPSS.

Tabel 13.

Hasil Uji t

\begin{tabular}{llll}
\hline Variabel & $\begin{array}{l}\text { Unstandardized } \\
\text { Coefficients Beta }\end{array}$ & t hitung & Sig. \\
\hline Leader member exchange & $-0,198$ & $-4,919$ & 0 \\
Kelelahan emosional & 0,436 & 6,217 & 0 \\
\hline
\end{tabular}

Sumber : Data diolah, 2018

Berdasarkan hasil analisis diperoleh nilai sig uji $\mathrm{t}=0,000<0,05$ maka $\mathrm{H}_{0}$ ditolak, artinya leader member exchange memiliki pengaruh yang signifikan terhadap turnover intention, koefisien regresi $X_{1}$ sebesar -0,198, secara negatif menunjukkan bahwa peningkatan kualitas leader member exchange sebesar 1 akan menurunkan turnover intention karyawan sebesar 0,198.

Berdasarkan hasil analisis diperoleh nilai sig uji $\mathfrak{t}=0,000<0,05$ maka $\mathrm{H}_{0}$ ditolak, artinya variabel kelelahan emosional berpengaruh secara signifikan terhadap turnover intention, koefisien regresi $\mathrm{X}_{2}$ sebesar 0,436 , secara positif menunjukkan bahwa peningkatan kelelahan emosional akan meningkatkan turnover intention sebesar 0,436.

Pengujian hipotesis pengaruh leader member exchange terhadap turnover intention dengan (Sig. t $0,000<0,05)$ dan koefisien beta $-0,198$ berarti leader 
member exchange berpengaruh negatif signifikan terhadap turnover intention sebesar -0,198, jadi, hasil penelitian ini mendukung hasil penelitian terdahulu yang dilakukan oleh (Gerstner \& Day, 1997) menunjukkan bahwa LMX memiliki dampak negatif terhadap turnover intention, Darrat et al. (2016) yang menyatakan bahwa LMX berpengaruh negatif terhadap turnover intention, Ksama \& Wibawa (2016) yang menunjukkan bahwa LMX berpengaruh negatif dan signifikan terhadap turnover intention.

Pengujian hipotesis pengaruh kelelahan emosional terhadap turnover intention dengan (Sig. t $0,000<0,05$ ) dan koefisien beta sebesar 0,436 berarti kelelahan emosional berpengaruh positif dan signifikan terhadap turnover intention sebesar 0,436. Hasil ini sejalan dengan penelitian terdahulu oleh (Chau et al., 2009) menemukan adanya hubungan positif antara kelelahan emosional dengan turnover intention. Cropanzano et al. (2003) yang menemukan bahwa kelelahan emosional dapat memungkinkan pekerja untuk mencari alternatif pekerjaan yang lebih tinggi dan penelitian Mahmoud et al. (2016) yang menunjukkan bahwa kelelahan emosional berpengaruh positif pada turnover intention dengan skala 0.561 .

Berdasarkan hasil penelitian ini, diketahui bahwa stress kerja memiliki pengaruh yang positif signifikan terhadap kelelahan emosional dengan demikian perusahaan diharapkan mampu menjaga kondisi kerja yang mampu memicu stress bagi para pekerjanya dalam hal ini adalah para karyawan pertokoan dalung. Selain menciptakan suasana kerja yang tidak memicu stress program pelatihan stres dapat juga diberikan pada para karyawan dengan tujuan agar karyawan dalam hal ini adalah para karyawan pertokoan dalung memiliki daya tahan terhadap stres dan memiliki kemampuan lebih baik untuk mengatasi stres. Dalam pelatihan stres karyawan memperoleh pelatihan mempergunakan dan mengembangkan sumbersumber energi yang ada dalam dirinya. Agar memperoleh hasil yang maksimal, maka pelatihan harus ditangani orangorang yang ahli dalam bidang pelatihan stres pada pekerjaan.

\section{SIMPULAN}

Berdasarkan hasil pembahasan penelitian, maka dapat disimpulkan bahwa:Leader member exchange berpengaruh negatif dan signifikan terhadap Turnover intention karyawan. Hal tersebut berarti semakin baik Leader member exchange, maka akan semakin rendah Turnover intention karyawan.Kelelahan emosional berpengaruh positif dan signifikan terhadap Turnover intention karyawan. Hal tersebut berarti kelelahan emosional yang tinggi, mengakibatkan peningkatan Turnover intention karyawan.

Saran-saran yang dapat diberikan adalah sebagai berikut item pernyataan terendah pada variabel LMX adalah "Atasan saya membela saya dari atasan lainnya meski tidak menguasai duduk perkaranya", maka hal ini menunjukkan bahwa atasan melakukan pengambilan keputusan yang tepat dan bijaksana dengan mengedepankan rasionalitas untuk memahami duduk perkara sebelm membela bawahan dari atasan lainnya. Item pernyataan tertinggi pada variabel kelelahan emosional adalah "saya merasa bosan dalam bekerja", maka perusahaan diharapkan bisa memberikan pelatihan bagi karyawan dalam menangani rasa 
bosan, pelatihan dapat berupa pelatihan yang mendatangkan mentor dari luar perusahaan maupun atasan dari internal toko itu sendiri yang diharapkan dapat meningkatkan kepercayaan dan kebanggaan karyawan terhadap atasannya. Item pernyataan tertinggi pada variabel turnover intention adalah "saya ingin mencoba pengalaman baru di bidang yang berbeda", sejalan dengan usia muda karyawan mendambakan prospek pada pekerjaan bidang lain yang dianggap lebih menjanjikan, padahal sejatinya seluruh pekerjaan itu sama kapasitasnya tergantung bagaimana karyawan dalam menyikapi pekerjaan tersebut, maka pengarahan dan penataran karyawan sangat penting dilakukan sebelum memulai pekerjaan agar mengerti tentang pentingnya fokus dalam bekerja.

Penelitian masa mendatang dirasa perlu untuk menggunakan variabel lain dari manajemen sumber daya manusia seperti kompensasi finansial, motivasi, disiplin kerja dan variabel lain yang mempengaruhi turnover intention.Penelitian masa mendatang perlu untuk memperluas cakupan wilayah penelitian dengan responden yang berbeda selain karyawan pertokoan Dalung Permai, tetapi dapat merambah wilayah lainnya.

\section{REFERENSI}

Ashkanasy, N. M., Hartel, C. E. J., \& Daus, C. S. (2002). Diversity and emotion: The new frontiers in organizational behavior research. Journal of Management, 28(3), 307-338.

Babakus, E., Cravens, D. W., Johnston, M., \& Moncrief, W. C. (1999). The Role of Emotional Exhaustion in Sales Force Attitude and Behavior relationship. Journal of the Academy of Marketing Science., 27(1), 58-70.

Boles, J. S., Johnston, M. W., \& Hair., J. J. F. (1997). "Role Stress, Work-Family Conflict and Emotional Exhaustion: Inter-relationships and Effects on Some Work-Related Consequences,." Journal of Personal Selling and Sales Management, 17(1), 17-28.

Caputo, J. S. (1991). Stress and burnout in library service. Canada: the Oryx Press.

Cascio, W. F. (1987). Applied pshycology in personel management. New Jersey: Prentice-Hall Inc.

Chau, S. L., Dahling, J. J., Levy, P. L., \& Diefendorff., J. M. (2009). “A Predictive Study of Emotional Labor and Turnover,." Journal of Organizational Behavior, 30(8), 63-1151.

Cherniss, C. (2001). Emotional Intelligence And Organizational Effectiveness.

Churiyah, M. (2011). Pengaruhi Konflik Peran, Kelelahan Emosional terhadap Kepuasan Kerja dan Komitmen Organisasi. Jurnal Ekonomi Bisnis, 16(2), 586-598.

Cropanzano, Russell, Rupp, D. E., \& Byrne., Z. S. (2003). "The Relationship of Emotional Exhaustion to Work Attitudes, Job Performance, and Organizational Citizenship Behaviors,." Journal of Applied Psychology, 88(1), 69-160.

Darrat, M., Atinc, G., \& Babin, B. J. (2016). On The Dysfunctional Consequences Of Salesperson Exhaustion. Journal of Marketing Theory and Practice, $24(2), 236-245$. 
DeConinck, J. B. (2011). "The Effects of Leader-Member Exchange and Organizational Identification on Performance and Turnover among Salespeople." Journal of Personal Selling and Sales Management, 31(1), 2134.

Gerstner, C. R., \& Day., D. V. (1997). "Meta-analytic Review of Leader-Member Exchange Theory: Correlates and Construct issues,." Journal of Applied Psychology, 82(6), 84-827.

Gilmer, V. H. (1966). Industrial Pshycology. USA.: McGraw Hill Book Company Inc.

Handoyo, R. (1987). Hubungan Keikatan terhadap Perusahaan dengan Kepuasan Kerja, Absensi dan Intensi Turnover Karyawan Pada PT. Busana Rama Textil dan Garment di Tangerang Jawa Barat. (Skripsi (t). Yogyakarta: Fakultas Psikologi UGM.

Harnoto. (2002). Manajemen Sumber Daya Manusia. (2nd ed.). Jakarta: PT Prehallindo.

Hartati, T. (1992). Hubungan Antara Persepsi terhadap Peluang Pengembangan Karir dengan Intensi Turnover pada Karyawan PT. Rajawali Nusantara Indonesia di Jakarta. Skripsi (Tidak Diterbitkan).

Houkes, I., Janssen., P. P. M., Jonge, J. de, \& Bakker, A. B. (2003). Specific determinants of intrinsic work motivation, emotional exhaustion and turnover intention: a multisample longitudional study. Journal of Occupational and Organizational Psychology, 60(10), 123-156.

Ivancevich, J. M., Konopaske, R., \& Matteson, M. T. (2007). Perilaku Dan Manajemen Organisasi. (7th ed.). Jakarta: Erlangga.

Jones, E., Chonko, L., Rangarajan, D., \& Roberts., J. (2007). "The Role of Overload on Job Attitudes, Turnover intentions, and Salesperson Performance,." Journal of Business Research, 60(7), 71-663.

Kent, G., Cravens, D. W., Low, G. S., \& C.Moncrief, W. (2001). "The Role Of Satisfaction With Territory Design On The Motivation, Attitudes, And Work Outcomes Of Salespeople,." Journal Of The Academy Of Marketing Science, 29(2), 165-178.

Kim, A., Michàlle, E., \& Barak, M. (2014). The mediating roles of leadermember exchange and perceived organizational support in the role stressturnover intention relationship among child welfare workers: A longitudinal analysis. Children and Youth Services Review.

Ksama, I. B. P. T., \& Wibawa., I. M. A. (2016). "Pengaruh Leader-Member Exchange, Role Stress Dan Perceived Organizational Support Terhadap Turnover Intention.” E-Jurnal Manajemen Unud, 5(10), 6174-6200.

Kumar, R., Charles, R., \& Peter, Y. (2011). A Study on Turnover intention in Fast Food Industry: Employees' Fit to the Organizational Culture and the Important of their Commitment. International Journal of Academic Research in Business and Social Sciences, 2(5), 9-42.

Lekatompessy, J. . (2003). Hubungan Profesionalisme dengan konsekuensinya: Komitmen Organisasional, Kepuasan Kerja, Prestasi Kerja dan Keinginan Berpindah (Studi Empiris di Lingkungan Akuntan Publik). Jurnal Bisnis Dan Akuntansi, 5(1), 69-84. 
Liden, R. C., \& Maslyn, J. M. (1998). Multidimensionality of leader-member exchange: An empirical assessment through scale development. Journal of Management, 24(1), 43-72.

Lum, L. K. (1998). Explaining Nursing Turnover Intent: Job Satisfaction, Pay Satisfaction, or Organizational Commitment. Journal Of Organizational Behavior, 19(3), 845-855.

Mahmoud, D., Atinc, G., \& Babin, B. J. (2016). On The Dysfunctional Consequences Of Salesperson Exhaustion. Journal of Marketing Theory and Practice, 24(2), 236-245.

Maslach, Schaufeli, C. W. ., \& Leiter, M. P. . (2001). Job Burnout. Arjournals Annual Reviews, 52, 397-422.

Nurjayadi, D. R. (2004). Turnover intention Pada Karyawan. Pronesis, 6(11), 4054.

Pines, A., \& Aronson, E. (1989). Career Burnout : Causes and Cures. New York: The Free Press, A Division of Macmillan, Inc.

Prawitasari, J. E. (2015). Psikologi Klinis: Pengantar Terapan Mikro dan Makro. Jakarta: Erlangga S.

Richardson, R. (1999). "Measuring the Impact of Turnover on Sales,." Journal of Personal Selling and Sales Management, 19(4), 53-66.

Robins, S. P., \& Judge, T. A. (2008). Organizational Behavior. US: Prentice Hall.

Shen, Y., Jackson, T., Ding, C., Yuan, D., Zhao, L., Dou, Y., \& Zhang, Q. (2014). Linking perceived organizational support with employee work outcomes in a Chinese context: Organizational identification as a mediator. European Management Journal, 406-412.

Siregar, S. (2014). Statistik Parametrik Untuk Penelitian Kuantitatif Dilengkapi Dengan Penghitungan Manual Dan Aplikasi SPSS Versi 17. Jakarta: Bumi Aksara.

Sugiyono. (2017). Metodologi Penelitian Kuantitatif, Kualitatif, dan R\&D. Bandung: CV Alfabeta.

Usman, A. (2012). Pengaruh Gaya Kepemimpinan dan Self Efficiency terhadap Kelelahan Emosional, Kepuasaan Kerja dan Komitmen Organisasi serta dampaknya terhadap Penyimpangan Organisasi pada Inspektorat kabupaten / kota di Sulawesi Selatan.

Widiastuti, D. Z., \& Kamsih., A. (2008). Hubungan Antara Kepribadian Hardiness Dengan Turnover intention Pada Guru Sekolah Dasar. Jurnal InSight, 6(2).

Yukl, G. (2004). Leadership in Organizations (6th ed.). New Jersey: Prentice-Hall Inc.

Zaglady, A. L. (2005). Pengaruh Kelelahan Emosional Terhadap Kepuasan kerja dan kinerja dalam pencapaian komitmen organisasi. 